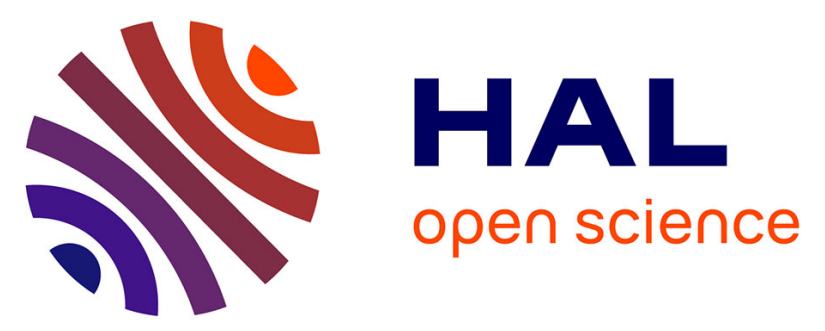

\title{
From global to local genetic structuring in the red gorgonian Paramuricea clavata: the interplay between oceanographic conditions and limited larval dispersal
}

K. Mokhtar-Jamai, M. Pascual, Ledoux J.-B., R. Coma, Jean-Pierre Féral, J. Garrabou, D. Aurelle

\section{To cite this version:}

K. Mokhtar-Jamai, M. Pascual, Ledoux J.-B., R. Coma, Jean-Pierre Féral, et al.. From global to local genetic structuring in the red gorgonian Paramuricea clavata: the interplay between oceanographic conditions and limited larval dispersal. Molecular Ecology, 2011, 20, pp.3291-3305. 10.1111/j.1365294X.2011.05176.x . hal-00847206

\section{HAL Id: hal-00847206 https://hal.science/hal-00847206}

Submitted on 23 Jul 2013

HAL is a multi-disciplinary open access archive for the deposit and dissemination of scientific research documents, whether they are published or not. The documents may come from teaching and research institutions in France or abroad, or from public or private research centers.
L'archive ouverte pluridisciplinaire HAL, est destinée au dépôt et à la diffusion de documents scientifiques de niveau recherche, publiés ou non, émanant des établissements d'enseignement et de recherche français ou étrangers, des laboratoires publics ou privés. 


\title{
From global to local genetic structuring in the red gorgonian Paramuricea clavata: the interplay between oceanographic conditions and limited larval dispersal
}

\author{
K. MOKHTAR-JAMAÏ,* M. PASCUAL,† J.-B. LEDOUX,* R. COMA, J.-P. FÉRAL, ${ }^{*} J$. GARRABOU*§ \\ and D. AURELLE* \\ *Aix-Marseille Université, CNRS UMR 6540 DIMAR, Centre d'Océanologie de Marseille, Station Marine d'Endoume, Chemin \\ de la Batterie des Lions, 13007 Marseille, France, tDepartment of Genetics, Universitat de Barcelona, Diagonal 645, 08028 \\ Barcelona, Spain, ‡Centre d'Estudis Avançats de Blanes (CEAB-CSIC), Accés Cala Sant Francesc 14, 17300 Blanes, Girona, \\ Catalonia, Spain, §Institut de Ciències del Mar CSIC, Passeig Maritim de la Barceloneta 37-49, E-08003 Barcelona, Spain
}

\begin{abstract}
Defining the scale of connectivity among marine populations and identifying the barriers to gene flow are tasks of fundamental importance for understanding the genetic structure of populations and for the design of marine reserves. Here, we investigated the population genetic structure at three spatial scales of the red gorgonian Paramuricea clavata (Cnidaria, Octocorallia), a key species dwelling in the coralligenous assemblages of the Mediterranean Sea. Colonies of $P$. clavata were collected from 39 locations across the Mediterranean Sea from Morocco to Turkey and analysed using microsatellite loci. Within three regions (Medes, Marseille and North Corsica), sampling was obtained from multiple locations and at different depths. Three different approaches (measures of genetic differentiation, Bayesian clustering and spatially explicit maximum-difference algorithm) were used to determine the pattern of genetic structure. We identified genetic breaks in the spatial distribution of genetic diversity, which were concordant with oceanographic conditions in the Mediterranean Sea. We revealed a high level of genetic differentiation among populations and a pattern of isolation by distance across the studied area and within the three regions, underlining short effective larval dispersal in this species. We observed genetic differentiation among populations in the same locality dwelling at different depths, which may be explained by local oceanographic conditions and which may allow a process of local adaptation of the populations to their environment. We discuss the implications of our results for the conservation of the species, which is exposed to various threats.
\end{abstract}

Keywords: conservation biology, genetic structure, larval dispersal, mediterranean Sea, microsatellites, paramuricea clavata

Received 21 February 2011; revision received 16 May 2011; accepted 2 June 2011

\section{Introduction}

Dispersal plays a major role in driving marine population connectivity and dynamics, and understanding the level of population connectivity is fundamental to develop suitable conservation strategies and for the

Correspondence: Kenza Mokhtar-Jamaï or Didier Aurelle, Fax: +33 491 041635; E-mails: mokhtarjamaikenza@hotmail.com; didier.aurelle@univmed.fr design of marine reserves (Shanks et al. 2003; Palumbi 2004; Almany et al. 2009). However, determining the scale at which dispersal occurs in marine sessile invertebrates is challenging as tracking gametes and larvae in the field is a tough task and barriers to dispersal are much less obvious in marine environment than in terrestrial one (Palumbi 1992, 1994). Molecular markers may be used to distinguish populations, to estimate gene flow among them, to assess demographic parameters and to unveil the signatures of historical and 
current processes that shaped the genetic landscape of populations (Manel et al. 2003; Hellberg 2009). Several genetic studies have shown that oceanographic barriers (Baums et al. 2006; Patarnello et al. 2007; Galarza et al. 2009; Sala-Bozano et al. 2009) and biological characteristics in marine invertebrates are shaping the genetic structure of the species (Duran et al. 2004; Ledoux et al. 2010a), suggesting that population connectivity might depend on intrinsic dispersal abilities of the species as well as physical barriers from the environment. Nevertheless, the interplay between life history traits and oceanographic barriers on the genetic structure of the species is not always predictable (Patarnello et al. 2007; Galarza et al. 2009). Therefore, uncovering population genetic patterns for many species across a shared environment can help to disentangle species-specific effects from environmental effects (Kelly \& Palumbi 2010).

In the context of the threats that global changes represent for littoral ecosystems worldwide (IPCC 2007), understanding connectivity for coastal marine species has become a priority for the conservation of these ecosystems. A major effort has been devoted to assess connectivity in a wide variety of taxa in coral reef ecosystems (Van Oppen \& Gates 2006; Jones et al. 2009), because of the documented decline in coral cover in recent decades (Gardner et al. 2003; Bruno \& Selig 2007) related to local and global stressors (Hughes et al. 2003). During the last decade, the coralligenous assemblages of the Mediterranean Sea, whose main structural components are low-turnover organisms (Coma et al. 1998; Garrabou et al. 2002), have also suffered from various local and global threats such as pollution, fishing, diving, invasive species and mass mortality events possibly linked to climate change (Ballesteros 2006). However, despite these threats and the need to extend our knowledge of population dynamics and connectivity for conservation and ecosystem-based management purposes (Gaines et al. 2010), genetic studies on species from the coralligenous assemblages are still scarce (see Abbiati et al. 2009 for a review). Previous genetic studies revealed strong population genetic structure and limited larval dispersal for some coralligenous species such as the red coral Corallium rubrum (Costantini et al. 2007a; b; Ledoux et al. 2010b) or the sponge Crambe crambe (Duran et al. 2004), even at small scales (Ledoux et al. 2010b, Calderón et al. 2007; Ledoux et al. 2010a; respectively). However, these studies did not always simultaneously include different spatial scales (but see Ledoux et al. 2010b), which can provide more insight into the importance of various factors in shaping genetic patterns.

The red gorgonian, Paramuricea clavata (Risso, 1826), is a colonial and sessile marine invertebrate inhabiting the Mediterranean coralligenous assemblages. This spe- cies is a long-lived (50-100 years) and slow-growing gorgonian (Coma et al. 1998). Paramuricea clavata acts as an ecosystem engineer, playing an important role in the structural complexity and maintenance of biomass and biodiversity in the associated assemblages (True 1970; Ballesteros 2006). It is widely distributed in the western part of the Mediterranean Sea and in the Adriatic Sea (Carpine \& Grasshof 1975) where it exhibits a discontinuous distribution. Red gorgonians are less commonly found in the Aegean Sea (Öztürk et al. 2004) and in the neighbouring Atlantic Ocean (J. G Harmelin, personal communication). The bathymetric distribution of the species extends from $5 \mathrm{~m}$ to beyond $200 \mathrm{~m}$ (P. Chevaldonné \& T. Pérez, personal communication). However, the species exhibits a decrease in depth of its upper limit distribution along the latitudinal gradient (Linares et al. 2008a). Paramuricea clavata is a gonochoric surface brooder species (Coma et al. 1995). Once released, the planula larvae display negative phototaxis behaviour (Linares et al. 2008b) and remain in suspension for a few minutes before dropping to the bottom (Coma et al. 1995). However, the larval phase can span between 6 and 23 days under experimental conditions (Linares et al. 2008b). The assemblages shaped by red gorgonians constitute one of the most attractive seascapes in the Mediterranean Sea (Harmelin \& Marinopoulos 1994). However, this species is affected by the previously mentioned threats to coralligenous assemblages, including mass mortality events (Cerrano et al. 2000; Linares et al. 2005; Garrabou et al. 2009), which have serious consequences at the population and colony levels (Linares et al. 2005, 2008c).

The aim of this study was to unveil the genetic structure of a sessile and long-lived species, Paramuricea clavata, across the Mediterranean Sea, at three spatial scales: global $(3000 \mathrm{~km})$, regional (from 200 to $52 \mathrm{~km}$ ) and local (over depth ranges, from 10 to $40 \mathrm{~m}$ ). More specifically, we (i) assessed the genetic diversity and population structure of this species over its distribution range (global scale), (ii) evaluated connectivity among populations within three regions (regional scale) and at different depths within the same locality (local scale) and (iii) identified putative barriers to gene flow. Finally, we discuss the implications of our results for the conservation of $P$. clavata and other species of the coralligenous assemblages, one of the most biodiversity-rich communities in the Mediterranean Sea.

\section{Materials and methods}

\section{Sampling design}

Paramuricea clavata colonies were randomly collected by SCUBA diving following a hierarchical sampling design. 
Thirty-nine locations or depths were sampled within the Mediterranean Sea to cover most of the distribution range of the species and to allow the study of genetic structure at distances varying from $10 \mathrm{~m}$ to $3000 \mathrm{~km}$ (Fig. 1; Table 1). Three regions (Medes, Marseille and North Corsica) were sampled at multiple locations, and five locations (Pota del Llop, Pharillons, Grotte Pérès, Petit Congloué and Riou Sud) were sampled at two different depths (Table 1). For each site, about 30 colonies of approximately the same height (approximately $15 \mathrm{~cm}$ ) were sampled and a small fragment preserved in $95 \%$ ethanol at $-20{ }^{\circ} \mathrm{C}$ prior to extraction.

\section{Microsatellite genotyping and polymorphism}

Total genomic DNA was extracted from 1114 individuals using a salting out procedure adapted from Miller et al. (1988) (see Supporting Information for
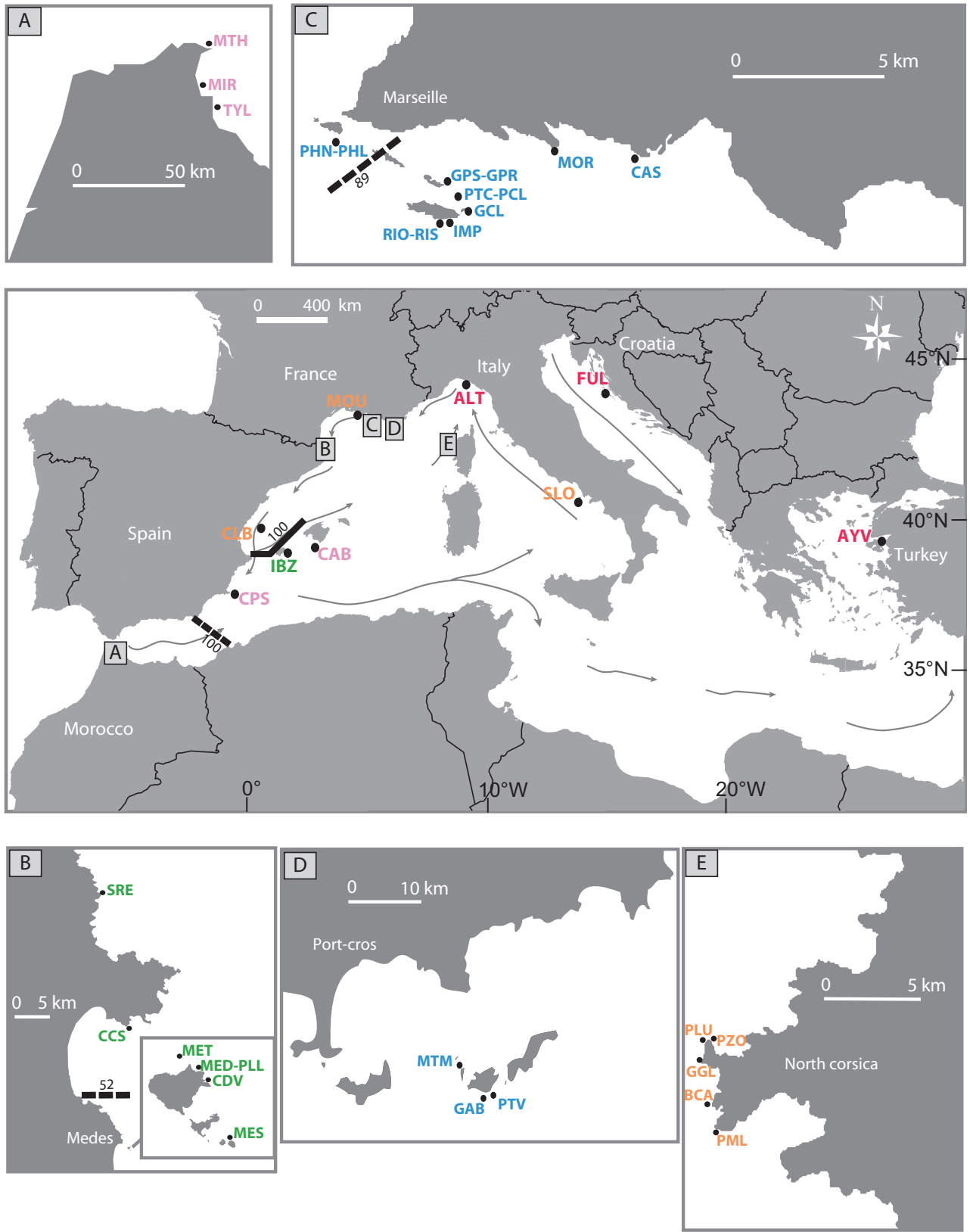

Fig. 1 Map of the 39 Paramuricea clavata samples (black dots). Samples collected at two different depths in the same location are separated by a hyphen. The colours of the sample names correspond to their assignment to STRUCTURE clusters for $K=5$. Details of samples are given in Table 1. The dominant sea surface currents according to Pinardi \& Masetti (2000) are indicated by grey arrows. Black solid and black-dotted lines represent the location of the main genetic breaks as revealed by BARRIER during the analysis at Mediterranean scale and the within cluster analysis, respectively (the associated bootstrap values are given). 
Table 1 Location of Paramuricea clavata samples

\begin{tabular}{|c|c|c|c|c|c|c|}
\hline \multirow[b]{2}{*}{ Basin } & \multirow[b]{2}{*}{ Location name } & \multirow[b]{2}{*}{ Population label } & \multicolumn{2}{|c|}{ GPS coordinates } & \multirow[b]{2}{*}{ Depth (m) } & \multirow[b]{2}{*}{ Sample size } \\
\hline & & & Latitude & Longitude & & \\
\hline Alboran Sea & Monte Hacho (Ceuta, Spain) & MTH & $35^{\circ} 55^{\prime} 5.78^{\prime \prime} \mathrm{N}$ & $5^{\circ} 17^{\prime} 59.27^{\prime \prime} \mathrm{O}$ & 26 & 27 \\
\hline Alboran Sea & Marinasmir (Morocco) & MIR & $35^{\circ} 45^{\prime} 6.00^{\prime \prime} \mathrm{N}$ & $5^{\circ} 18^{\prime} 48.00^{\prime \prime} \mathrm{O}$ & 40 & 27 \\
\hline Alboran Sea & Martyl (Morocco) & TYL & $35^{\circ} 38^{\prime} 30.00^{\prime \prime} \mathrm{N}$ & $5^{\circ} 14^{\prime} 54.00^{\prime \prime} \mathrm{O}$ & 35 & 27 \\
\hline Alboran Sea & Bajo de Fuera (Cap de Palos, Spain) & CPS & $37^{\circ} 39^{\prime} 8.64^{\prime \prime} \mathrm{N}$ & $0^{\circ} 39^{\prime} 8.62^{\prime \prime} \mathrm{O}$ & 40 & 28 \\
\hline Balearic Sea & Bledes (Na Gorra) (Ibiza Island, Spain) & IBZ & $38^{\circ} 58^{\prime} 13.21^{\prime \prime} \mathrm{N}$ & $1^{\circ} 40^{\prime} 11.93^{\prime \prime} \mathrm{E}$ & 37 & 30 \\
\hline Balearic Sea & L'Imperial (Cabrera Island, Spain) & $\mathrm{CAB}$ & $39^{\circ} 7^{\prime} 25.40^{\prime \prime} \mathrm{N}$ & $2^{\circ} 57^{\prime} 37.22^{\prime \prime} \mathrm{E}$ & 40 & 19 \\
\hline Balearic Sea & Bajo del Carallot (Columbretes Island, Spain) & CLB & $39^{\circ} 53^{\prime} 32.40^{\prime \prime} \mathrm{N}$ & $0^{\circ} 40^{\prime} 13.55^{\prime \prime} \mathrm{E}$ & 40 & 26 \\
\hline Catalan Sea & Carall Bernat (Medes Islands, Spain) & MES & $42^{\circ} 2^{\prime} 31.92^{\prime \prime} \mathrm{N}$ & $3^{\circ} 13^{\prime} 41.38^{\prime \prime} \mathrm{E}$ & 20 & 24 \\
\hline Catalan Sea & Cova de la Vaca (Medes Islands, Spain) & $\mathrm{CDV}$ & $42^{\circ} 2^{\prime} 52.97^{\prime \prime} \mathrm{N}$ & $3^{\circ} 13^{\prime} 34.76^{\prime \prime} \mathrm{E}$ & 17 & 36 \\
\hline Catalan Sea & Pota del Llop (Medes Islands, Spain) & MED & $42^{\circ} 2^{\prime} 58.92^{\prime \prime} \mathrm{N}$ & $3^{\circ} 13^{\prime} 31.44^{\prime \prime} \mathrm{E}$ & 15 & 27 \\
\hline Catalan Sea & Pota del llop (Medes Islands, Spain) & PLL & $42^{\circ} 2^{\prime} 58.92^{\prime \prime} \mathrm{N}$ & $3^{\circ} 13^{\prime} 31.44^{\prime \prime} \mathrm{E}$ & 35 & 27 \\
\hline Catalan Sea & Medallot (Medes Islands, Spain) & MET & $42^{\circ} 3^{\prime} 5.62^{\prime \prime} \mathrm{N}$ & $3^{\circ} 13^{\prime} 18.31^{\prime \prime} \mathrm{E}$ & 20 & 27 \\
\hline Catalan Sea & Punta Falconera (Cap de Creus) & CCS & $42^{\circ} 13^{\prime} 56.89^{\prime \prime} \mathrm{N}$ & $3^{\circ} 13^{\prime} 7.95^{\prime \prime} \mathrm{E}$ & 25 & 27 \\
\hline Catalan Sea & Sec Rederis (Banyuls, France) & SRE & $42^{\circ} 27^{\prime} 50.76^{\prime \prime} \mathrm{N}$ & $3^{\circ} 9^{\prime} 59.69^{\prime \prime} \mathrm{E}$ & 20 & 27 \\
\hline Gulf of Lion & Tombant Moulon Est (Cote Bleue, France) & MOU & $43^{\circ} 19^{\prime} 51.00^{\prime \prime} \mathrm{N}$ & $5^{\circ} 14^{\prime} 22.00^{\prime \prime} \mathrm{E}$ & 20 & 27 \\
\hline Gulf of Lion & Pharillons (Marseille, France) & PHN & $43^{\circ} 12^{\prime} 26.64^{\prime \prime} \mathrm{N}$ & $5^{\circ} 20^{\prime} 17.52^{\prime \prime} \mathrm{E}$ & 20 & 27 \\
\hline Gulf of Lion & Pharillons (Marseille, France) & PHL & $43^{\circ} 12^{\prime} 26.64^{\prime \prime} \mathrm{N}$ & $5^{\circ} 20^{\prime} 17.52^{\prime \prime} \mathrm{E}$ & 40 & 28 \\
\hline Gulf of Lion & Grotte Peres (Marseille, France) & GPS & $43^{\circ} 11^{\prime} 11.62^{\prime \prime} \mathrm{N}$ & $5^{\circ} 23^{\prime} 28.16^{\prime \prime} \mathrm{E}$ & 10 & 29 \\
\hline Gulf of Lion & Grotte Peres (Marseille, France) & GPR & $43^{\circ} 11^{\prime} 11.62^{\prime \prime} \mathrm{N}$ & $5^{\circ} 23^{\prime} 28.16^{\prime \prime} \mathrm{E}$ & 20 & 38 \\
\hline Gulf of Lion & Petit Congloue (Marseille, France) & PTC & $43^{\circ} 10^{\prime} 45.33^{\prime \prime} \mathrm{N}$ & $5^{\circ} 23^{\prime} 43.92^{\prime \prime} \mathrm{E}$ & 10 & 33 \\
\hline Gulf of Lion & Petit Congloue (Marseille, France) & PCL & $43^{\circ} 10^{\prime} 45.33^{\prime \prime} \mathrm{N}$ & $5^{\circ} 23^{\prime} 43.92^{\prime \prime} \mathrm{E}$ & 20 & 27 \\
\hline Gulf of Lion & Grand Congloue (Marseille, France) & GCL & $43^{\circ} 10^{\prime} 32.79^{\prime \prime} \mathrm{N}$ & $5^{\circ} 24^{\prime} 6.62^{\prime \prime} \mathrm{E}$ & 7 & 35 \\
\hline Gulf of Lion & Imperiales de Terre (Marseille, France) & IMP & $43^{\circ} 10^{\prime} 22.79^{\prime \prime} \mathrm{N}$ & $5^{\circ} 23^{\prime} 35.39^{\prime \prime} \mathrm{E}$ & 8 & 33 \\
\hline Gulf of Lion & Riou Sud (Marseille, France) & RIO & $43^{\circ} 10^{\prime} 21.66^{\prime \prime} \mathrm{N}$ & $5^{\circ} 23^{\prime} 25.16^{\prime \prime} \mathrm{E}$ & 20 & 31 \\
\hline Gulf of Lion & Riou Sud (Marseille, France) & RIS & $43^{\circ} 10^{\prime} 21.66^{\prime \prime} \mathrm{N}$ & $5^{\circ} 23^{\prime} 25.16^{\prime \prime} \mathrm{E}$ & 40 & 26 \\
\hline Gulf of Lion & Morgiou (Marseille, France) & MOR & $43^{\circ} 12^{\prime} 3.36^{\prime \prime} \mathrm{N}$ & $5^{\circ} 27^{\prime} 5.22^{\prime \prime} \mathrm{E}$ & 30 & 31 \\
\hline Gulf of Lion & Castelvieil (Marseille, France) & CAS & $43^{\circ} 11^{\prime} 51.36^{\prime \prime} \mathrm{N}$ & $5^{\circ} 29^{\prime} 55.50^{\prime \prime} \mathrm{E}$ & 10 & 30 \\
\hline Ligurian Sea & Montremian (Port-Cros, France) & MTM & $43^{\circ} 1^{\prime} 7.15^{\prime \prime} \mathrm{N}$ & $6^{\circ} 21^{\prime} 45.98^{\prime \prime} \mathrm{E}$ & 20 & 29 \\
\hline Ligurian Sea & Gabiniere (Port-Cros, France) & GAB & $42^{\circ} 59^{\prime} 21.54^{\prime \prime} \mathrm{N}$ & $6^{\circ} 23^{\prime} 49.18^{\prime \prime} \mathrm{E}$ & 22 & 32 \\
\hline Ligurian Sea & Pointe du Vaisseau (Port-Cros, France) & PTV & $42^{\circ} 59^{\prime} 42.92^{\prime \prime} \mathrm{N}$ & $6^{\circ} 24^{\prime} 24.17^{\prime \prime} \mathrm{E}$ & 20 & 29 \\
\hline Ligurian Sea & Palazzinu (North Corsica, France) & $\mathrm{PZO}$ & $42^{\circ} 22^{\prime} 46.69^{\prime \prime} \mathrm{N}$ & $8^{\circ} 32^{\prime} 58.13^{\prime \prime} \mathrm{E}$ & 25 & 27 \\
\hline Ligurian Sea & Palazzu (North Corsica, France) & PLU & $42^{\circ} 22^{\prime} 48.65^{\prime \prime} \mathrm{N}$ & $8^{\circ} 32^{\prime} 46.85^{\prime \prime} \mathrm{E}$ & 28 & 27 \\
\hline Ligurian Sea & Garganellu (North Corsica, France) & GGL & $42^{\circ} 22^{\prime} 21.36^{\prime \prime} \mathrm{N}$ & $8^{\circ} 32^{\prime} 12.84^{\prime \prime} \mathrm{E}$ & 20 & 27 \\
\hline Ligurian Sea & Baja Casju (North Corsica, France) & BCA & $42^{\circ} 20^{\prime} 58.56^{\prime \prime} \mathrm{N}$ & $8^{\circ} 33^{\prime} 3.42^{\prime \prime} \mathrm{E}$ & 25 & 27 \\
\hline Ligurian Sea & Punta Muchillina (North Corsica, France) & PML & $42^{\circ} 19^{\prime} 55.92^{\prime \prime} \mathrm{N}$ & $8^{\circ} 33^{\prime} 12.51^{\prime \prime} \mathrm{E}$ & 20 & 27 \\
\hline Ligurian Sea & Altare (Portofino, Italy) & ALT & $44^{\circ} 18^{\prime} 20.40^{\prime \prime} \mathrm{N}$ & $9^{\circ} 11^{\prime} 45.90^{\prime \prime} \mathrm{E}$ & 25 & 36 \\
\hline Tyrrhenian Sea & Sant'Angelo (Ischia Island, Italy) & SLO & $40^{\circ} 41^{\prime} 30.98^{\prime \prime} \mathrm{N}$ & $13^{\circ} 53^{\prime} 36.69^{\prime \prime} \mathrm{E}$ & 32 & 27 \\
\hline Adriatic Sea & Fulija Island (dugi otok) (Croatia) & FUL & $44^{\circ} 1^{\prime} 5.52^{\prime \prime} \mathrm{N}$ & $15^{\circ} 6^{\prime} 39.96^{\prime \prime} \mathrm{E}$ & 40 & 31 \\
\hline Aegean Sea & Ayvalik (Ezerbey Sigiligi) (Turkey) & AYV & $39^{\circ} 22^{\prime} 12.23^{\prime \prime} \mathrm{N}$ & $26^{\circ} 34^{\prime} 36.21^{\prime \prime} \mathrm{E}$ & 35 & 21 \\
\hline
\end{tabular}

details). All individuals were genotyped at six microsatellite loci: Parcla 09, Parcla 10, Parcla 12, Parcla 14, Parcla 17 (Molecular Ecology Resources Primer Development Consortium et al. 2010) and Par_d (Agell et al. 2009). All the loci were amplified according to the PCR protocol described in Molecular Ecology Resources Primer Development Consortium et al. (2010). PCR products were analysed on an ABI 3130 Genetic Analyser using an internal size standard (GeneScan 600 LIZ; Applied Biosystems). GeneMapper v.3.5 software (Applied Biosystems) was used to score alleles.
We used MICRO-CHECKER v.2.2.3 (Van Oosterhout et al. 2004) to check for scoring errors owing to stutters, large allele dropout and to estimate null allele frequencies.

Linkage disequilibrium was tested among all pairs of loci in each sample with a permutation test $(n=1000)$ using GENETIX v.4.05 (Belkhir et al. 2004). Tests for Hardy-Weinberg equilibrium within sample for each locus and over all loci were conducted with GENEPOP v.4.0 (Rousset 2008). The level of significance was determined by a Markov chain method (Guo \& Thompson 1992) using the default parameters. Single 
and multilocus Weir \& Cockerham's (1984) $f$ estimator of $F_{\text {IS }}$ were computed with GENEPOP.

We analysed the genetic diversity for each sample by computing observed (Ho) and Nei's (1973) unbiased expected heterozygosity (He) with GENETIX. Allelic richness $[\mathrm{Ar}(\mathrm{g})]$ and private allelic richness $[\mathrm{Ap}(\mathrm{g})]$ were estimated with a rarefaction procedure using the HP-RARE software (Kalinowski 2005) with the minimum number of genes set to 18 .

\section{Analysis of genetic structure at different spatial scales and estimation of dispersal}

We investigated population structure using different approaches: measures of genetic differentiation ( $F_{\mathrm{ST}}$, $D_{\text {EST }}$ ), a Bayesian clustering method, a hierarchical analysis of molecular variance and a spatially explicit maximum-difference algorithm. For the measures of genetic differentiation, samples were used as population unit. We computed Weir \& Cockerham's (1984) $\theta$ estimator of $F_{\mathrm{ST}}$ with GENEPOP. As null alleles can induce overestimation of genetic distance (Chapuis \& Estoup 2007), pairwise $F_{\mathrm{ST}}$ estimates were also computed following the excluding null allele (ENA) method in FREENA (Chapuis \& Estoup 2007). Jost's (2008) measure of genetic differentiation $\left(D_{\mathrm{EST}}\right)$ was computed with SMOGD v.1.2.5 (Crawford 2010). We tested the significance of pairwise genotypic differentiation between samples with an exact test as implemented in GENEPOP using the default parameters.

The pattern of isolation by distance (IBD) at Mediterranean scale and within the three regions was tested through the correlation between pairwise $F_{\mathrm{ST}} /\left(1-F_{\mathrm{ST}}\right)$ values and the logarithm of the geographical distances between populations by a Mantel test ( $n=10000$ randomizations; Rousset 1997) with IBDWS 3.16 (Jensen et al. 2005).

The Bayesian method implemented in STRUCTURE v.2.2 (Pritchard et al. 2000; Falush et al. 2003, 2007) was used to evaluate the number of clusters $(K)$ in our data set from individual's genotypes without prior information on their geographical locations. STRUCTURE was launched under the admixture model, with correlated allele frequencies among clusters and the recessive allele option to cope with null alleles (Falush et al. 2007). Ten independent runs were performed for each $\mathrm{K}$ using 500000 iterations and a burn-in period of 50 000. As suggested by Rosenberg et al. (2001, 2002) and Jakobsson et al. (2008) for cases of large data sets, we adopted a hierarchical approach. As detection of population structure at fine-scale levels is indeed limited when the data set is large, this approach thus allows for a more complete description of the patterns of structure (see for example Garnier et al. 2004; Wang et al. 2007; Ledoux et al. 2010b). We first ran STRUCTURE on the whole data set (i.e. Mediterranean scale) with $K$ varying from 1 to 15 . Because no single $K$ value provided a full description of population structure because of the additional substructure (Jakobsson et al. 2008), we discussed the values between 2 and 5. The clustering solution observed for $K=5$ was then retained to subdivide the samples into five data sets for a second round of STRUCTURE for the study at regional scale (with $K$ varying from 1 to the maximum number of samples within each cluster). Given the current debate on how to estimate the number of clusters (Pritchard et al. 2000; Evanno et al. 2005; Waples \& Gaggiotti 2006; François \& Durand 2010), we opted for the 'standard and conservative' approach of Pritchard et al. (2007) to select a $\mathrm{K}$ value for this second round of clustering. We plotted the $\log$ probability of the data $(\mathrm{LnP}(\mathrm{D}))$ as a function of $\mathrm{K}$ across the 10 runs and looked for the value that captured the major structure in the data (Pritchard et al. 2007). CLUMPP v.1.1 (Jakobsson \& Rosenberg 2007) was used to merge the results across the 10 runs for a given $\mathrm{K}$ when a single clustering solution was found; otherwise, only runs with the same mode (symmetric similarity coefficient $>0.9$ ) were merged, and the most frequently occurring mode was retained. DISTRUCT v.1.1 (Rosenberg 2004) was used to visualize the results.

ARLEQUIN v.3.5 (Excoffier et al. 2005) was used to perform hierarchical analysis of molecular variance (AMOVA, $n=1000$ permutations) using the groups defined by STRUCTURE for $K=5$ (see Results).

We ran the software BARRIER v. 2.2 (Manni et al. 2004) to identify barriers to gene flow represented by zones of abrupt change in the pattern of genetic variation on the whole data set (i.e. Mediterranean scale) and within each STRUCTURE cluster (i.e. regional scale). The software computes barriers on a Delaunay triangulation (built with GPS coordinates) using Monmonier's (1973) maximum-difference algorithm (with pairwise $F_{\mathrm{ST}}$ matrix). The robustness of the identified barriers was tested with 100 resampled bootstrap matrices created with an $\mathrm{R}$ function (Eric Petit, UMR ECOBIO CNRS, Paimpont, personal communication).

We used a Bayesian assignment method (Rannala \& Mountain 1997) as implemented in GENECLASS2 (Piry et al. 2004) to identify putative first-generation migrants among populations. A Monte Carlo resampling method was performed to compute individual probability of assignment to each population (Paetkau et al. 2004) using 10000 simulated individuals.

We computed with SPAGEDI (Hardy \& Vekemans 2002) the relationship coefficient Moran's I (1948) among pairwise individuals belonging to the same location and depth and among pairwise individuals belong- 
ing to the same location but to different depths. For each location, statistical differences between mean Moran's I values among individuals from the same location and depth and mean Moran's I value among individuals from the same location but different depths were investigated with a Kruskal-Wallis ANOvA.

Whenever multiple tests were conducted, the level of significance was adjusted using a false discovery rate (FDR) (Benjamini \& Hochberg 1995).

\section{Results}

\section{Genetic variability}

No evidence of large allele dropout or scoring errors owing to stutters was found using MICRO-CHECKER. No global significant linkage disequilibrium among loci was found ( $P>0.05$ after FDR correction) on the overall samples. All the loci were polymorphic with total number of alleles ranging from 10 for Par_d to 35 for Parcla 09 and Parcla 12 and with a mean value of 25 alleles per locus. Observed and unbiased expected heterozygosities ranged from 0.58 for TYL to 0.83 for PZO and from 0.56 for AYV to 0.81 for PHL, respectively (with a mean value of 0.69 and 0.74 , respectively) (Table 2). The allelic richness $\operatorname{Ar}(18)$ varied from 4.41 (FUL) to 7.55 (PHL). Significant differences in allelic richness were observed between the five clusters defined by STRUCTURE (Kruskal-Wallis, $P=0.001$ ) with higher values found in clusters 2, 3 and 4 (7.0, 6.61 and 6.30, respectively) and lower values in clusters 5 and 1 (4.93 and 5.93, respectively). The private allelic richness Ap(18) ranged from 0 (CLB, CCS, PHN, GCL, CAS, PTV, PLU, PML) to 0.72 (TYL), and no differences were observed when comparing the five clusters $(P=0.097)$. Multilocus $F_{\mathrm{IS}}$ values ranged between -0.11 for $\mathrm{AYV}$ and 0.23 for TYL (Table 2). Over all loci, significant heterozygote deficiencies were found in 23 samples of 39 (after FDR correction). Examining each locus separately, $F_{\text {IS }}$ values ranged from -0.448 for Parcla 09 in AYV sample to 0.705 for Parcla 12 in MTH (Table S1, Supporting Information). Heterozygote deficiency was not generalized for all loci in all samples. In case of departure from Hardy-Weinberg equilibrium, evidence for null allele was checked and null allele frequencies were computed at each locus in each sample. The estimates of null allele frequencies varied between 0.07 for Parcla 09 in MED sample and 0.28 for Parcla 12 in MIR sample, with a mean value of 0.14 over all loci and samples (Table S1, Supporting Information). However, in some cases, the $\mathrm{F}_{\mathrm{IS}}$ value was significant but no evidence of null allele was detected according to MICRO-CHECKER (Table S1, Supporting Information).
Table 2 Estimators of genetic diversity in 39 samples of $P$. clavata at six microsatellite loci

\begin{tabular}{|c|c|c|c|c|c|c|}
\hline Population & Ho & $\mathrm{He}$ & $\mathrm{Na}$ & $\operatorname{Ar}(18)$ & $A p(18)$ & f \\
\hline MTH & 0.62 & 0.78 & 9.67 & 6.45 & 0.1 & 0.21 \\
\hline MIR & 0.64 & 0.75 & 8.33 & 5.98 & 0.28 & 0.11 \\
\hline TYL & 0.58 & 0.77 & 10.17 & 6.56 & 0.72 & 0.23 \\
\hline CPS & 0.62 & 0.73 & 7.5 & 5.58 & 0.01 & 0.15 \\
\hline IBZ & 0.65 & 0.66 & 8.67 & 5.44 & 0.12 & 0.01 \\
\hline $\mathrm{CAB}$ & 0.69 & 0.67 & 6.17 & 5.07 & 0.29 & -0.02 \\
\hline CLB & 0.66 & 0.77 & 8 & 6.03 & 0 & 0.17 \\
\hline MES & 0.72 & 0.73 & 9.33 & 6.88 & 0.01 & 0.01 \\
\hline $\mathrm{CDV}$ & 0.69 & 0.73 & 10.33 & 6.59 & 0.08 & 0.06 \\
\hline MED & 0.75 & 0.78 & 10.33 & 7.11 & 0.06 & 0.04 \\
\hline PLL & 0.71 & 0.75 & 11.5 & 7.43 & 0.13 & 0.05 \\
\hline MET & 0.63 & 0.71 & 10.17 & 6.99 & 0.06 & 0.11 \\
\hline CCS & 0.69 & 0.75 & 9.67 & 6.54 & 0 & 0.08 \\
\hline SRE & 0.6 & 0.7 & 9.17 & 5.9 & 0.04 & 0.11 \\
\hline MOU & 0.75 & 0.77 & 8 & 6.12 & 0.02 & 0.02 \\
\hline PHN & 0.68 & 0.74 & 8.33 & 6.58 & 0 & 0.1 \\
\hline PHL & 0.75 & 0.81 & 11.5 & 7.55 & 0.13 & 0.07 \\
\hline GPS & 0.68 & 0.72 & 10.5 & 6.7 & 0.01 & 0.07 \\
\hline GPR & 0.76 & 0.77 & 12.5 & 7.44 & 0.16 & 0.02 \\
\hline PTC & 0.73 & 0.8 & 11 & 7.35 & 0.02 & 0.08 \\
\hline PCL & 0.74 & 0.77 & 10.5 & 7.44 & 0.01 & 0.04 \\
\hline GCL & 0.77 & 0.8 & 9.33 & 6.92 & 0 & 0.03 \\
\hline IMP & 0.71 & 0.75 & 12.33 & 7.47 & 0.11 & 0.06 \\
\hline RIO & 0.65 & 0.76 & 11.67 & 7.52 & 0.02 & 0.16 \\
\hline RIS & 0.7 & 0.75 & 11 & 7.05 & 0.01 & 0.07 \\
\hline MOR & 0.72 & 0.76 & 10.67 & 7.23 & 0.01 & 0.05 \\
\hline CAS & 0.61 & 0.71 & 8.67 & 6.38 & 0 & 0.14 \\
\hline MTM & 0.63 & 0.68 & 8.17 & 5.66 & 0.04 & 0.07 \\
\hline GAB & 0.7 & 0.76 & 10.67 & 7.24 & 0.05 & 0.07 \\
\hline PTV & 0.66 & 0.67 & 9.83 & 6.46 & 0 & 0.03 \\
\hline $\mathrm{PZO}$ & 0.83 & 0.78 & 10.17 & 6.95 & 0.07 & -0.07 \\
\hline PLU & 0.8 & 0.78 & 8.17 & 6.32 & 0 & -0.01 \\
\hline GGL & 0.7 & 0.76 & 9.17 & 6.67 & 0.08 & 0.06 \\
\hline $\mathrm{BCA}$ & 0.73 & 0.78 & 8.33 & 6.1 & 0.09 & 0.07 \\
\hline PML & 0.68 & 0.71 & 7.5 & 5.59 & 0 & 0.04 \\
\hline ALT & 0.66 & 0.69 & 8.5 & 5.76 & 0.04 & 0.04 \\
\hline SLO & 0.67 & 0.77 & 9 & 6.59 & 0.19 & 0.13 \\
\hline FUL & 0.63 & 0.66 & 6 & 4.41 & 0.06 & 0.04 \\
\hline AYV & 0.61 & 0.56 & 6.17 & 4.63 & 0.13 & -0.11 \\
\hline Mean Value & 0.69 & 0.74 & 9.4 & 6.48 & 0.08 & 0.07 \\
\hline
\end{tabular}

Ho, observed heterozygosity; He, unbiased expected heterozygosity; Na, number of alleles; $\operatorname{Ar}(18)$ and $\mathrm{Ap}(18)$, rarefied allelic and private allelic richness, respectively (with rarefaction size of 18); $f$, Weir \& Cockerham's (1984) $f$ estimator of $F_{\text {IS }}$ with significant values in bold ( 0.05 threshold after FDR correction).

\section{Population genetic structure}

Overall $F_{\mathrm{ST}}$ value was strong (0.116), and the exact test indicated a highly significant differentiation. Pairwise $F_{\mathrm{ST}}$ values (Table S2, Supporting Information) ranged from 0.004 for PLL vs. MET to 0.330 for IBZ vs. AVY. No significant differences were observed between 
pairwise $F_{\mathrm{ST}}$ and pairwise $F_{\mathrm{ST}}$ corrected for null alleles ( $t$-test, $P=0.219)$, suggesting that null alleles did not affect this analysis. Pairwise $D_{\text {EST }}$ values (Table S2, Supporting Information) ranged from 0.001 for MET vs. PLL to 0.738 for SLO vs. TYL with a mean value of 0.319. All pairwise differentiation tests were significant except 6 of 741 (after FDR correction). The nonsignificant comparisons included samples from Medes separated by distances of 920 and $370 \mathrm{~m}$ (MES vs. PLL and PLL vs. MET, respectively); samples from Marseille separated by $1220 \mathrm{~m}$ (PCL vs. IMP); and samples belonging to the same location but to different depths from Medes and Marseille (MED vs. PLL; PTC vs. PCL; and GPS vs. GPR separated by 20, 10 and $10 \mathrm{~m}$, respectively). Significant genetic differentiation was observed between some samples collected at different depths and separated by $20 \mathrm{~m}$ (PHN vs. PHL and RIO vs. RIS).

Positive and significant correlation between $F_{\mathrm{ST}} /$ $\left(1-F_{\mathrm{ST}}\right)$ values and the logarithm of the geographical distances was found $\left(R^{2}=0.509, P<0.0001\right)$, suggesting a strong pattern of IBD at Mediterranean scale (Fig. 2). Within the three regions, Medes, Marseille and North Corsica, a pattern of IBD was also evidenced $\left(R^{2}=0.584, P=0.026 ; R^{2}=0.080, P=0.031 ;\right.$ and $R^{2}=$ $0.264, \quad P=0.046$, respectively) (Fig. S1, Supporting Information). Similar patterns of IBD were observed with $D_{\text {EST }}$ (data not shown).

For the first round of STRUCTURE, the plot of $\mathrm{LnP}(\mathrm{D})$ as a function of $\mathrm{K}$ did not reveal a clear pla-

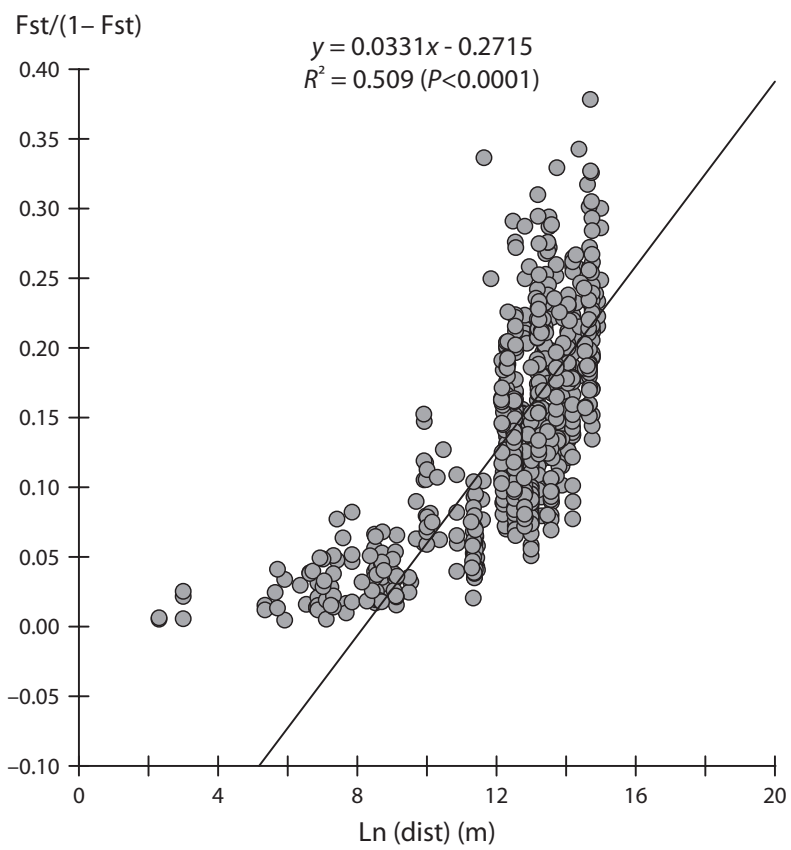

Fig. 2 Correlation between genetic distances computed as $F_{\mathrm{ST}} /\left(1-F_{\mathrm{ST}}\right)$ and the logarithm of geographical distances $(\mathrm{m})$ between sample pairs. teau but a weak increase in $\mathrm{LnP}(\mathrm{D})$ values from $K=1$ to 15 (Fig. S2, Supporting Information). For $K=2$, the main separation appeared between samples from the Alboran Sea, the Balearic Sea (CAB, CLB) and the Ligurian Sea (North Corsica) (cluster 1) and samples from the Gulf of Lion (Marseille) and the Ligurian Sea (Port-Cros and Portofino) (cluster 2) (Fig. 3). All other samples were more or less equally assigned to each of the two clusters. For $K=3$, samples from the Catalan Sea, one sample from the Balearic Sea (IBZ) and samples from the Ligurian Sea (North Corsica, except PLU) were grouped in a third cluster. For $K=4$, samples from the Ligurian Sea (North Corsica) (cluster 4) were clearly distinguished from samples from the Catalan Sea. At $K=5$, a fifth cluster appeared with one sample from the Ligurian Sea (Portofino, ALT) and the samples from the Adriatic and Aegean Seas (FUL and AYV, respectively). Overall, the five clusters were congruent with the geographical origin of the samples, with a few exceptions: IBZ, CAB, CLB from the Balearic Sea were not grouped together; MOU from Côte Bleue (Gulf of Lion) and SLO from the Tyrrhenian Sea were clustered with North Corsican samples (Ligurian Sea); and ALT from the Ligurian Sea was gathered with FUL and AYV from eastern Mediterranean Sea (Adriatic and Aegean Seas, respectively). Each of the five clusters was analysed for a second round. During the second round, the value that captured the major structure in the data was retained. For cluster $1, \mathrm{~K}$ was set to 3 with the three samples from the Moroccan coast grouping together and CPS and CAB representing each a cluster. For cluster 2, K was set to 3 . Samples from Port-Cros (MTM, GAB and PTV) and MOR belonged to one cluster, another grouped PHN, PHL and RIS and the third GPS and GPR, whereas the other samples from Marseille showed a high proportion of admixture of these two last clusters. For cluster $3, K=3$ was the retained solution with one cluster regrouping all the samples from Medes and IBZ and CCS/SRE representing each a cluster. For cluster 4 , the retained solution was $K=4$. The samples from North Corsica were divided into 2 clusters: [PZO, PLU, PML] and [GGL, BCA] with PML displaying a high coefficient of population membership and the other samples exhibiting a high level of admixture. For cluster 5, the retained solution was $K=3$ with ALT, FUL and AYV representing their own cluster.

The AMOVA revealed a highly significant genetic structuring among the STRUCTURE groups, among samples within groups and within samples $(P<0.001$; Table 3$)$. The percentage of genetic variation explained by differences among groups was almost equal to the percentage of genetic variation explained by differences among samples within groups $(6.0 \%$ and $7.2 \%$, respectively), 

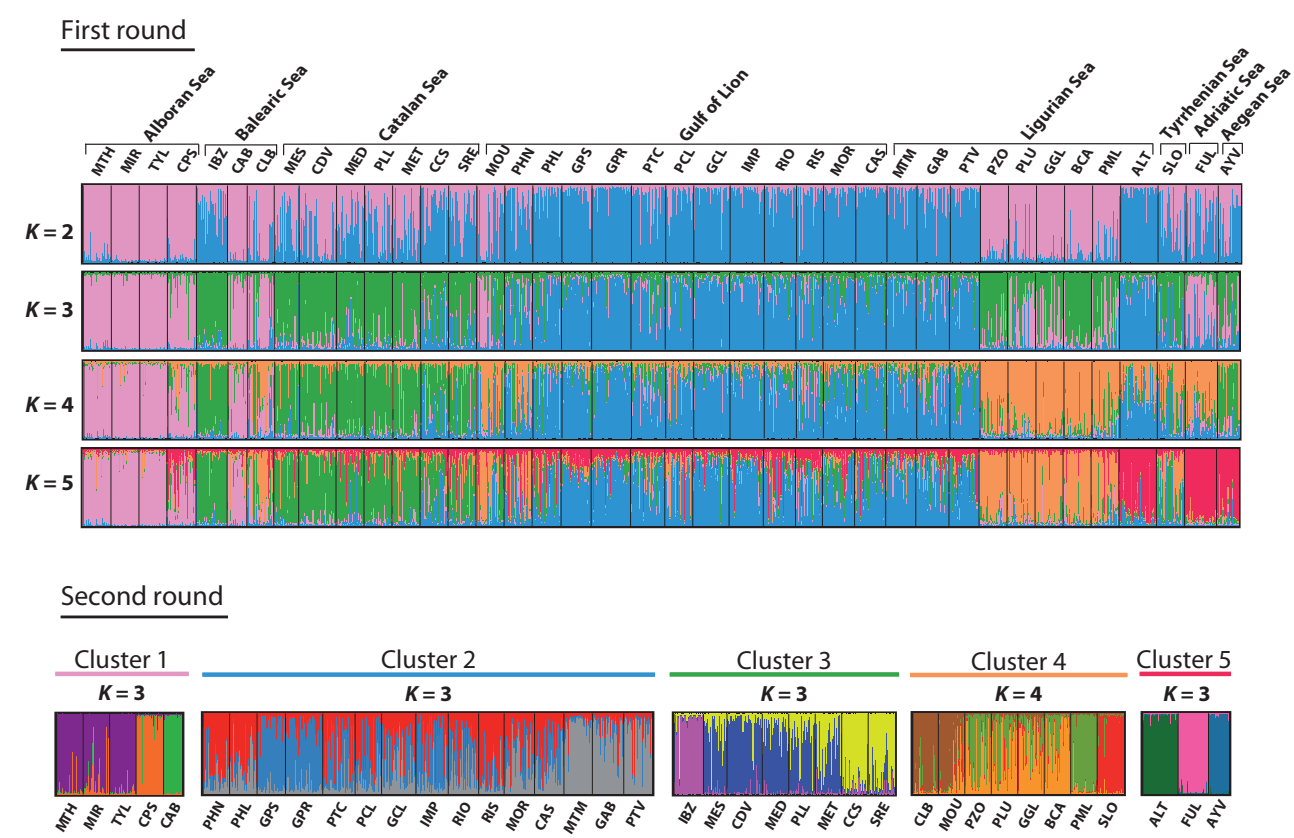

Fig. 3 Bar plot from the Bayesian clustering analysis with STRUCTURE, revealing population structure of $P$. clavata during the first round (first five panels) and second round (last panel).

Table 3 Analysis of molecular variance (AMOVA) of P. clavata samples grouped according to STRUCTURE clusters

\begin{tabular}{lrrr}
\hline Source of variation & d.f. & $\%$ of variance & $P$-value \\
\hline STRUCTURE clusters $K=5$ & & & \\
$\quad$ Among groups & 4 & 6.0 & $<0.001$ \\
Among samples within group & 34 & 7.2 & $<0.001$ \\
Within samples & 2105 & 86.8 & $<0.001$ \\
\hline
\end{tabular}

and the highest percentage of genetic variation was found within samples $(86.8 \%$ ) (Table 3 ).

The software BARRIER revealed the occurrence of sharp breaks in genetic differentiation (barriers) across the studied area. However, given our geographical sampling scheme, we have considered only the most relevant barrier that was located for the global analysis between the Balearic Islands and the Spanish coast and between the northern and southern Spanish coast around the Ibiza channel (Fig. 1, solid line). This barrier was supported by a bootstrap value of 100 . We ran BARRIER a second time inside each STRUCTURE cluster by simulating one barrier (Fig. 1, dotted lines). For cluster 1, the barrier appeared between MTH/MIR/TYL and CPS/CAB (bootstrap value of 100). Within cluster 2, the break was located between the 2 western samples of Marseille and the remaining samples (bootstrap value of 89). For cluster 3 , the barrier was placed between the samples from Medes and CCS/SRE but had a low bootstrap value (52\% bootstrap). Within cluster 4 , the barrier separated CLB/MOU from all other samples (87\% bootstrap). For cluster 5, the genetic break was located between ALT and the samples from the eastern basin (100\% bootstrap). These two last barriers were not represented in Fig. 1 as they involved samples situated far apart and they could not be unambiguously located.

Populations exchanged very few migrants, according to GENECLASS2, with only $3.9 \%$ of the individuals detected as migrants (Table S3, Supporting Information). The origin of almost all detected migrants was consistent with predominant surface currents, and the mean distance travelled from their population of origin was estimated at $160 \mathrm{~km}$.

At the local scale, we aimed to assess the effect of depth on genetic structuring. To evaluate the genetic similarity between individuals collected in the same location, the mean pairwise Moran's I values among individuals from the same location and depth and among individuals from the same location but different depths were computed (Table 4). For three locations (Pota del Llop, Grotte Pérès and Petit Congloué), the mean pairwise Moran's I values among individuals from the same depth were low and not significantly different from the mean pairwise Moran's I value among individuals separated by depth. For the two locations with samples at 20 and $40 \mathrm{~m}$ (Pharillons and Riou Sud), the mean pairwise Moran's I values among individuals from the same depth were high and significantly higher than the mean pairwise Moran's I value among individuals separated by depth. 


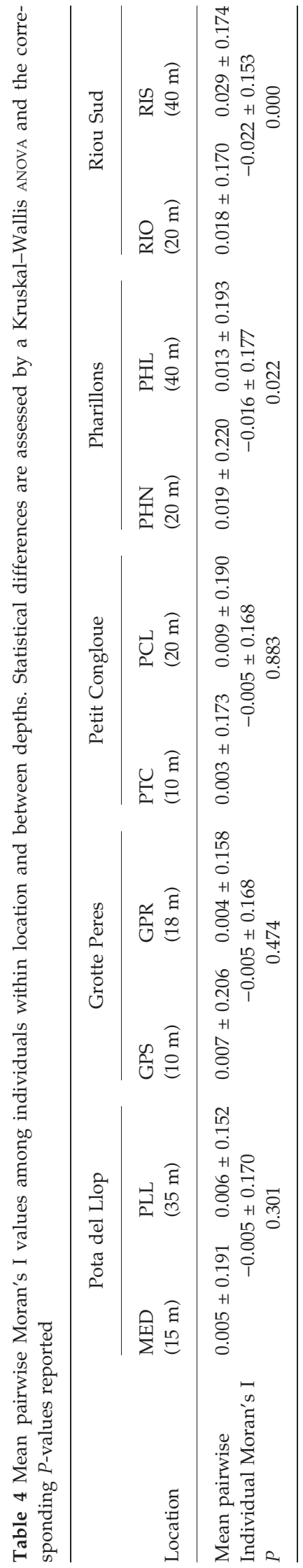

\section{Discussion}

The analysis of six microsatellite loci evidenced strong genetic differentiation among populations of Paramuricea clavata separated by distances ranging from thousands kilometres to twenty metres. A strong pattern of isolation by distance was observed at the global as well as the regional scales. At the local scale, depth differentiation was also found in some locations. At the sample level, we observed a high level of genetic diversity and heterozygote deficiency. Many populations of sessile marine invertebrates from different taxa, displaying restricted larval dispersal, exhibit departure from Hardy-Weinberg equilibrium because of heterozygote deficiency, such as sponges (Duran et al. 2004), corals (Polato et al. 2010), ascidians (Pérez-Portela \& Turon 2008; Dupont et al. 2009) and gorgonians (Gutiérrez-Rodríguez \& Lasker 2004; Ledoux et al. 2010a,b). Several factors may contribute to the observed heterozygote deficiencies, such as null alleles, inbreeding and temporal and spatial Wahlund effects (Addison \& Hart 2005). Although we detected null alleles, they were not generalized in all samples for which we observed heterozygote deficiency. Thus, biological factors may also contribute to explain the observed heterozygote deficiencies. The reproductive biology of this species may lead to inbreeding because: (i) females brood the eggs on their surface and thus the fertilization relies on sperm dispersal which, in other gorgonian species, has been documented to decrease at the scale of a few metres (Coma \& Lasker 1997a,b) and (ii) after release, many of the larvae of Paramuricea clavata settle near the putative maternal colony (Coma et al. 1995; Linares et al. 2008b). Combination of these two processes increases the probability of mating between related individuals. Inbreeding is a likely cause, yet spatial Wahlund effect could not be refuted as a possible explanation.

\section{Genetic structure at three spatial scales}

At the Mediterranean scale, Paramuricea clavata showed, over all loci, high and highly significant genetic structure. The first round of the Bayesian clustering method revealed discontinuities in the spatial distribution of genetic diversity congruent with the geographical locations of the samples (Fig. 3). A clear distinction between southern, northern-western and eastern samples within the Mediterranean Sea was revealed. In the north-western Mediterranean Sea, three clusters were, respectively, represented by samples from Medes (Catalan Sea), Marseille (Gulf of Lion) and North Corsica (Ligurian Sea) and tally with the genetic structure of Corallium rubrum within this region, which suggests that similar mechanisms may act on the genetic structure 
of these two species in the NW Mediterranean Sea (Ledoux et al. 2010b).

Hydrodynamic processes and oceanographic barriers in the Mediterranean Sea may contribute to the genetic structure of $P$. clavata. The strongest barrier identified may correspond to the joint effect of the Balearic front and the Ibiza channel. The Balearic front is a shelf/slope front produced by thermohaline differences between three surface water masses of the Balearic Sea and characterized by its mesoscale variability (García et al. 1994). This front has been reported to act as a barrier to gene flow between the Balearic Islands and the Spanish coast opposite, for several fish species whatever their early-life history traits (Galarza et al. 2009). The Balearic Sea, by its central position between the Liguro-Provençal and the Alboran/Algerian basins, plays an important role in the water circulation of the western Mediterranean Sea (García et al. 1994). The Mediterranean surface and intermediate waters encounter the less saline Atlantic waters at the Ibiza channel (Fernández et al. 2005). During spring and early summer, the formation of an anticyclonic gyre causes the deviation of the northern current to the Balearic Islands (Monserrat et al. 2008) impeding the water flow from crossing the Ibiza channel and to reaching the southern Spanish coast. Paramuricea clavata reproduces between June and July; thus, the southward larval transport along the Spanish coast may be hindered at the Ibiza channel by this gyre. The effect of the Ibiza channel reducing gene flow has been emphasized for the comber Serranus cabrilla (Schunter et al. unpublished) and the decapod crustacean Liocarcinus depurator (Garcia-Merchan et al. unpublished). Our results showed that the Balearic Sea is composed of a mix of gene pools from different origins: Catalan Sea (IBZ), Alboran Sea (CAB) and Ligurian Sea (CLB), which may be due to oceanographic conditions in this region. Several studies have highlighted the peculiar status of the Balearic region for the red coral Corallium rubrum (Ledoux et al. 2010b), the seagrass Posidonia oceanica (Rozenfeld et al. 2008) and the comber Serranus cabrilla (Schunter et al. unpublished), suggesting in this last study the occurrence of a mixing of gene pools of different origins, mediated by the oceanographic currents reaching this area, which is consistent with our findings. A second genetic barrier was located at the Almeria-Oran front. This front is a thermohaline density front generated by the convergence between the inflow of Atlantic water through the Strait of Gibraltar and the Mediterranean water. The Almeria-Oran front has been shown to represent a barrier to gene flow in numerous species (Patarnello et al. 2007; Galarza et al. 2009; Sala-Bozano et al. 2009) but does not affect all species (Patarnello et al. 2007; Garcia-Merchan et al. unpublished). This front seems to act as a weak barrier to gene flow in $P$. clavata.

Besides those genetic breaks, the significant and positive correlation between genetic differentiation and geographic distance suggested that distance is also a cause of barrier to gene flow in P. clavata. The regional pattern of isolation by distance underlined a short effective larval dispersal in this species, which is in agreement with the negative phototaxis behaviour of the larva, its short swimming period (Linares et al. 2008b) and its lecithotrophic character. A similar pattern of isolation by distance, with low larval dispersal ability, has already been reported for other Mediterranean sessile invertebrates (Duran et al. 2004; Blanquer \& Uriz 2010; Ledoux et al. 2010b but see Costantini et al. 2007b).

At regional scale, the three regions studied in $P$. clavata displayed a pattern of IBD. A similar pattern was observed for C. rubrum in the Medes and Marseille regions, whereas this species did not exhibit this pattern in North Corsica (Ledoux et al. 2010b). In P. clavata, gene flow seemed to occur mainly in the direction of the dominant surface current: southwards in Medes and northwards in North Corsica. In the Gulf of Lion, a distinction between samples from Marseille and the MOU sample from Côte Bleue was observed. The genetic distinction between the two sides of the Marseille area had already been observed by Lejeusne \& Chevaldonné (2006) in a cave-dwelling mysid, and the authors related it to a local hydrodynamic barrier. This barrier could be effective for $P$. clavata, and the high admixture found for PHN sample and the identification of a barrier at the regional scale might indicate a transition zone at this location. Nevertheless, this barrier was not observed for the red coral C. rubrum (Ledoux et al. 2010b). In Marseille, the distinction between the two main groups was not outright, supporting the occurrence of stochastic gene flow in this region with the influence of populations from Port-Cros that belong to a marine protected area. This result could explain the weak correlation found between genetic distance and geographic distance within this region. The summer circulation in the Gulf of Lion displays high spatiotemporal variability induced by different wind systems (Millot 1979), which may explain the stochastic pattern of genetic structure found in Marseille.

At local scale, the pattern of genetic structure between populations dwelling at different depths within the same location depended on the depth ranges. In Pota del Llop (15 and $35 \mathrm{~m}$ ), Grotte Pérès and Petit Congloue $(10$ and $20 \mathrm{~m})$, the results at the individual and population levels suggest the occurrence of gene flow between these depth ranges within the same location. In contrast, in Pharillons and Riou Sud 
(20 and $40 \mathrm{~m}$ ), the results/suggest restricted gene flow between 20 and $40 \mathrm{~m}$. Genetic differentiation over similar depth ranges within a single location has been recently emphasized in the coral reef species Seriatopora hystrix, although vertical migration was observed in north-west but not in north-east Australian reefs (Van Oppen et al. 2011). These differences in the patterns of gene flow over depths between reefs have been related to differences in coral bleaching-related mortality (Van Oppen et al. 2011). In our study, such a phenomenon is unlikely to have occurred as our sampled locations did not recently undergo severe disturbances and first-generation migrants were not detected at the locations where gene flow was observed between depths. Other factors can explain our contrasted patterns, such as local topography, water flow and the occurrence of the summer thermocline. The confirmation of this last hypothesis could be significant to explain differences at local scale for $P$. clavata and other benthic species with similar reproductive modes. In general, summer conditions are characterized by the presence of a thermocline located at approximately $20 \mathrm{~m}$ depth in the NW Mediterranean region (Bensoussan et al. 2010). The thermocline may act as a physical barrier to gene flow leading to genetic differentiation between populations dwelling on either side of the thermocline. In Medes, the thermocline is deeper than in Marseille (reaching $40 \mathrm{~m}$ depth) because of recurrent downwellings (Bensoussan et al. 2010), which may explain the occurrence of gene flow in Medes between 15 and $35 \mathrm{~m}$. The contrasted thermal regimes and the reduced gene flow between depths on either side of the thermocline may be a favourable factor for the evolution of local adaptation to temperature and depth. The occurrence of local adaptation within marine populations at small spatial scales has recently been reported in several species and may be more common than previously thought (Sanford \& Kelly 2011). Adaptation to local environment over a $30 \mathrm{~m}$ depth range has been suggested as a cause of genetic structure across habitats in Seriatopora hystrix (Bongaerts et al. 2010). Local adaptation to temperature within this depth range also seems likely for Corallium rubrum (Torrents et al. 2008), and genotype-environment interactions related to depth have been observed in common garden experiments in this species in one of the locations (Riou, Marseille) also studied in the present work (Ledoux 2010). Taking into account the observed genetic differentiation related to depth in that locality in two gorgonian species, common environmental factors leading to local adaptation could be shaping genetic variability associated with depth in that region. Nevertheless, further locations and samples from both sides of the thermocline as well as common garden experiments are required to study these hypotheses.
Thus, limited larval dispersal in combination with hydrodynamic conditions may strongly influence the genetic structure of sessile marine species at different spatial scales. The study at different scales is thus important to uncover the factors shaping the genetic patterns of the species and should be considered in future studies. Despite the strong genetic structure in $P$. clavata, some gene flow might be occurring over short and large distances (mean of $160 \mathrm{~km}$ ), which may be plausible given the potential duration of larval phase under experimental conditions (Linares et al. 2008b). However, the low percentage of migrants $(0-14 \%$ per population) suggests that migration events among populations are sporadic. Consequently, our results suggest that $P$. clavata populations mainly rely on self-recruitment (between $86 \%$ and $100 \%$, Table S3, Supporting Information).

\section{Consequences and implications for the conservation of Paramuricea clavata}

In the current context of global warming (IPCC 2007) and given the observed pattern of stratification enhancement owing to global warming (Coma et al. 2009) and the predictions of increased frequency of heat waves in the Mediterranean Sea (Diffenbaugh et al. 2007), our results regarding the evaluation of genetic diversity and population connectivity of $P$. clavata are of major importance to provide an assessment of population genetic data and a baseline for further genetic monitoring (Schwartz et al. 2007). Besides climatic threats, high diving activities have been shown to cause serious damages to red gorgonian populations by increasing their natural mortality rate (Coma et al. 2004). Simulations predicted that the combined effects of diving activities and the actual frequency of mass mortality events could lead populations to extinction within the near future (Linares \& Doak 2010). The recovery of populations that have been affected by strong disturbances appears to be very slow (Cerrano et al. 2005; Linares et al. 2005, 2008a; Cupido et al. 2008; Linares \& Doak 2010) because of the low dynamics of P. clavata populations (Coma et al. 1998, 2004; Linares et al. 2008a) and the low recruitment rates within populations (Coma et al. 2001). The high degree of population differentiation highlighted in this study suggests a limited effective dispersal, which implies that the recovery of populations will mainly rely on self-recruitment. However, at regional scale, sporadic gene flow may occur among $P$. clavata populations, most probably depending on hydrodynamic conditions. Thus, conservation plans for the Mediterranean red gorgonian should be defined at regional and local scales. Networks of marine reserves have been considered as a 
key conservation strategy to protect biodiversity (Jones et al. 2007). To achieve this aim of protection, the design of a marine reserve network should take into consideration (i) connectivity among populations as it will ensure population persistence, (ii) genetic diversity as it could enhance population resilience in the face of disturbances (Almany et al. 2009) and (iii) control of diving activities within reserves to limit the effects of the more controllable forms of human-induced impact.

An experimental and modelling approach for restoration has been undertaken on red gorgonian populations and has suggested the feasibility of such a strategy to help populations to recover after disturbances at local scale (Linares et al. 2008d). Our genetic survey may also help such restoration projects because genetic factors (Baums 2008), such as the genotypic diversity of transplanted individual or putative adaptation of the individuals to their environment of origin, should be considered to avoid loss of fitness in restored populations (Williams 2001; Baums 2008).

Paramuricea clavata is a structuring key species, which provides biogenic substrate, shade and shelter for other species of the associated assemblages (True 1970; Ballesteros 2006) that may thus indirectly suffer from the damages caused to red gorgonians (Ribes \& Coma 2005). Therefore, our study and the resulting guidelines for the conservation of the red gorgonian will enable the conservation of one of the most biodiversity-rich communities in the Mediterranean Sea.

\section{Acknowledgements}

We are grateful to B. Badr, A. Blanquer, O. Bianchimani, T. Ceylan, H. Cizmek, M.C Gambi, C. Linares, E. Macpherson, C. Marschal, O. Ocaña, T. Perez, M. Previati, O. Torrents and F. Zuberer for providing us with samples. We would like to thank C. Linares for helpful discussions, M. Sala-Bozano for helpful advices and G. Agell and C. Rocher for technical help. We thank Dr. Giacomo Bernardi and three anonymous reviewers for their useful comments that have enabled us to improve the earlier version of the manuscript. K.M.J.'s PhD was funded by the French Ministère de l'Enseignement Supérieur et de la Recherche. This research was partly supported by the MEDCHANGE project funded by the Agence Nationale pour la Recherche and research grants CGL2007-66757-C02-01 from the MEC.

\section{References}

Abbiati M, Costantini F, Fauvelot C (2009) Conservation of coralligenous reefs: effective larval dispersal, scales of connectivity and resilience. In: Proceedings of the 1st Mediterranean Symposium on the Conservation of the Coralligenous and Others Calcareous Bio-Concretions (eds Pergent-Martini C., Brichet M.). pp. 28-33, RAC/SPA Tabarka, Tunisie.
Addison J, Hart M (2005) Spawning, copulation and inbreeding coefficients in marine invertebrates. Biology Letters, 1, 450-453.

Agell G, Rius M, Pascual M (2009) Isolation and characterization of eight polymorphic microsatellite loci for the Mediterranean gorgonian Paramuricea clavata. Conservation Genetics, 10, $2025-$ 2027.

Almany GR, Connolly SR, Heath DD et al. (2009) Connectivity, biodiversity conservation and the design of marine reserve networks for coral reefs. Coral Reefs, 28, 339-351.

Ballesteros E (2006) Mediterranean coralligenous assemblages: a synthesis of present knowledge. Oceanography and Marine Biology:An Annual Review, 44, 123-195.

Baums IB (2008) A restoration genetics guide for coral reef conservation. Molecular Ecology, 17, 2796-2811.

Baums IB, Paris CB, Chérubin LM (2006) A bio-oceanographic filter to larval dispersal in a reef-building coral. Limnology and Oceanography, 51, 1969-1981.

Belkhir K, Borsa P, Chikhi L, Raufaste N, Bonhomme F (2004) GENETIX 4.05, Logiciel Sous Windows TM Pour La Génétique Des Populations. Laboratoire, Génome, Populations, Interactions, CNRS UMR 5000, Université de Montpellier II, Montpellier, France.

Benjamini Y, Hochberg Y (1995) Controlling the false discovery rate: a practical and powerful approach to multiple testing. Journal of the Royal Statistical Society. Series B (Methodological), 57, 289-300.

Bensoussan N, Romano J, Harmelin J, Garrabou J (2010) High resolution characterization of northwest Mediterranean coastal waters thermal regimes: to better understand responses of benthic communities to climate change. Estuarine, Coastal and Shelf Science, 87, 431-441.

Blanquer A, Uriz M (2010) Population genetics at three spatial scales of a rare sponge living in fragmented habitats. BMC Evolutionary Biology, 10, 13.

Bongaerts P, Riginos C, Ridgway T et al. (2010) Genetic divergence across habitats in the widespread coral Seriatopora hystrix and its associated Symbiodinium. PLoS ONE, 5, e10871.

Bruno JF, Selig ER (2007) Regional decline of coral cover in the Indo-Pacific: timing, extent, and subregional comparisons. PLOS ONE, 2, e711.

Calderón I, Ortega N, Duran S et al. (2007) Finding the relevant scale: clonality and genetic structure in a marine invertebrate (Crambe crambe, Porifera). Molecular Ecology, 16, 1799-1810.

Carpine C, Grasshof M (1975) Les gorgonaires de la Méditerranée. Bulletin de l'Institut Océanographique de Monaco, 71, 1-140.

Cerrano C, Bavestrello G, Bianchi C et al. (2000) A catastrophic mass-mortality episode of gorgonians and other organisms in the Ligurian Sea (North-western Mediterranean), summer 1999. Ecology Letters, 3, 284-293.

Cerrano C, Arillo A, Azzini F et al. (2005) Gorgonian population recovery after a mass mortality event. Aquatic Conservation: Marine and Freshwater Ecosystems, 15, 147-157.

Chapuis M, Estoup A (2007) Microsatellite null alleles and estimation of population differentiation. Molecular Biology and Evolution, 24, 621-631.

Coma R, Lasker HR (1997a) Effects of spatial distribution and reproductive biology on in situ fertilization rates of a broadcast-spawning invertebrate. Biological Bulletin, 193, 20-29. 
Coma R, Lasker HR (1997b) Small-scale heterogeneity of fertilization success in a broadcast spawning octocoral. Journal of Experimental Marine Biology and Ecology, 214, 107-120.

Coma R, Ribes M, Zabala M, Gili J (1995) Reproduction and cycle of gonadal development in the Mediterranean gorgonian Paramuricea clavata. Marine Ecology Progress Series, 117, 173-183.

Coma R, Ribes M, Zabala M, Gili J (1998) Growth in a modular colonial marine invertebrate. Estuarine, Coastal and Shelf Science, 47, 459-470.

Coma R, Linares C, Pola E, Zabala M (2001) Seguiment temporal de la gorgònia Paramuricea clavata de les illes Medes. Exercici 2001. In: Seguiment Temporal De L'àrea Marina Protegida De Les Illes Medes. Informe Annual Any 2001 (ed. Zabala M). pp. 59-82, Departament de Medi ambient, Generalitat de Catalunya, Barcelona.

Coma R, Pola E, Ribes M, Zabala M (2004) Long-term assessment of temperate octocoral mortality patterns, protected vs. unprotected areas. Ecological Applications, 14, $1466-1478$.

Coma R, Ribes M, Serrano E et al. (2009) Global warmingenhanced stratification and mass mortality events in the Mediterranean. Proceedings of the National Academy of Sciences, 106, 6176-6181.

Costantini F, Fauvelot C, Abbiati M (2007a) Fine-scale genetic structuring in Corallium rubrum: evidence of inbreeding and limited effective larval dispersal. Marine Ecology Progress Series, 340, 109-119.

Costantini F, Fauvelot C, Abbiati M (2007b) Genetic structuring of the temperate gorgonian coral (Corallium rubrum) across the western Mediterranean Sea revealed by microsatellites and nuclear sequences. Molecular Ecology, 16, 5168-5182.

Crawford NG (2010) SMOGD: software for the measurement of genetic diversity. Molecular Ecology Resources, 10, 556-557.

Cupido R, Cocito S, Sgorbini S, Bordone A, Santangelo G (2008) Response of a gorgonian (Paramuricea clavata) population to mortality events: recovery or loss? Aquatic Conservation: Marine and Freshwater Ecosystems, 18, 984-992.

Diffenbaugh NS, Pal JS, Giorgi F, Gao X (2007) Heat stress intensification in the Mediterranean climate change hotspot. Geophysical Research Letters, 34, 6.

Dupont L, Viard F, Dowell MJ, Wood C, Bishop JDD (2009) Fine- and regional-scale genetic structure of the exotic ascidian Styela clava (Tunicata) in southwest England, 50 years after its introduction. Molecular Ecology, 18, 442-453.

Duran S, Pascual M, Estoup A, Turon X (2004) Strong population structure in the marine sponge Crambe crambe (Poecilosclerida) as revealed by microsatellite markers. Molecular Ecology, 13, 511-522.

Evanno G, Regnaut S, Goudet J (2005) Detecting the number of clusters of individuals using the software structure: a simulation study. Molecular Ecology, 14, 2611-2620.

Excoffier L, Laval G, Schneider S (2005) Arlequin (version 3.0): an integrated software package for population genetics data analysis. Evolutionary Bioinformatics Online, 1, 47-50.

Falush D, Stephens M, Pritchard JK (2003) Inference of population structure using multilocus genotype data: linked loci and correlated allele frequencies. Genetics, 164, 1567-1587.

Falush D, Stephens M, Pritchard JK (2007) Inference of population structure using multilocus genotype data: dominant markers and null alleles. Molecular Ecology Notes, 7, 574-578.

Fernández V, Dietrich DE, Haney RL, Tintoré J (2005) Mesoscale, seasonal and interannual variability in the Mediterranean Sea using a numerical ocean model. Progress in Oceanography, 66, 321-340.

François O, Durand E (2010) The state of the field: Spatially explicit Bayesian clustering models in population genetics. Molecular Ecology Resources, 10, 773-784.

Gaines SD, White C, Carr MH, Palumbi SR (2010) Designing marine reserve networks for both conservation and fisheries management. Proceedings of the National Academy of Sciences, 107, 18286-18293.

Galarza JA, Carreras-Carbonell J, Macpherson E et al. (2009) The influence of oceanographic fronts and early-life-history traits on connectivity among littoral fish species. Proceedings of the National Academy of Sciences, 106, 1473-1478.

García MJL, Millot C, Font J, García-Ladona E (1994) Surface circulation variability in the Balearic Basin. Journal of Geophysical Research, 99, 3285-3296.

Gardner TA, Cote IM, Gill JA, Grant A, Watkinson AR (2003) Long-term region-wide declines in Caribbean corals. Science, 301, 958-960.

Garnier S, Alibert P, Audiot P, Prieur B, Rasplus J (2004) Isolation by distance and sharp discontinuities in gene frequencies: implications for the phylogeography of an alpine insect species, Carabus solieri. Molecular Ecology, 13, 1883-1897.

Garrabou J, Ballesteros E, Zabala M (2002) Structure and dynamics of North-western Mediterranean rocky benthic communities along a depth gradient. Estuarine, Coastal and Shelf Science, 55, 493-508.

Garrabou J, Coma R, Bensoussan N et al. (2009) Mass mortality in Northwestern Mediterranean rocky benthic communities: effects of the 2003 heat wave. Global Change Biology, 15, 10901103.

Guo SW, Thompson EA (1992) Performing the exact test of Hardy-Weinberg proportion for multiple alleles. Biometrics, 48, 361-372.

Gutiérrez-Rodríguez C, Lasker HR (2004) Microsatellite variation reveals high levels of genetic variability and population structure in the gorgonian coral Pseudopterogorgia elisabethae across the Bahamas. Molecular Ecology, 13, 2211-2221.

Hardy OJ, Vekemans X (2002) SPAGEDI: a versatile computer program to analyse spatial genetic structure at the individual or population levels. Molecular Ecology Notes, 2, 618-620.

Harmelin J, Marinopoulos J (1994) Population structure and partial mortality of the gorgonian Paramuricea clavata (Risso) in the North-Western Mediterranean (France, Port-Cros Island). Marine Life, 4, 5-13.

Hellberg ME (2009) Gene flow and isolation among populations of marine animals. Annual Review of Ecology, Evolution, and Systematics, 40, 291-310.

Hughes TP, Baird AH, Bellwood DR et al. (2003) Climate change, human impacts, and the resilience of coral reefs. Science, 301, 929-933.

IPCC (2007) Climate Change 2007: The Physical Science Basis. Contribution of Working Group I to the Fourth Assesment Report of the Intergovernmental Panel on Climate Change (eds Solomon SD, Qin M, Manning Z et al.). pp. 996, Cambridge University Press, Cambridge, UK and New York, NY, USA. 
Jakobsson M, Rosenberg NA (2007) CLUMPP: a cluster matching and permutation program for dealing with label switching and multimodality in analysis of population structure. Bioinformatics, 23, 1801-1806.

Jakobsson M, Scholz SW, Scheet P et al. (2008) Genotype, haplotype and copy-number variation in worldwide human populations. Nature, 451, 998-1003.

Jensen J, Bohonak A, Kelley S (2005) Isolation by distance, web service. BMC Genetics, 6, 13.

Jones G, Srinivasan M, Almany G (2007) Population connectivity and conservation of marine biodiversity. Oceanography, 20, 42-53.

Jones GP, Almany GR, Russ GR et al. (2009) Larval retention and connectivity among populations of corals and reef fishes: history, advances and challenges. Coral Reefs, 28, 307-325.

Jost L (2008) GST and its relatives do not measure differentiation. Molecular Ecology, 17, 4015-4026.

Kalinowski ST (2005) HP-RARE 1.0: a computer program for performing rarefaction on measures of allelic richness. Molecular Ecology Notes, 5, 187-189.

Kelly RP, Palumbi SR (2010) Genetic structure among 50 species of the Northeastern Pacific rocky intertidal community. PLoS ONE, 5, e8594.

Ledoux JB (2010) Biologie De La Conservation Du Corail Rouge, Corallium Rubrum (Linnaeus, 1758): Impact Du Changement Global Sur L'évolution Des Populations Infralittorales En Méditerranée Nord-Occidentale. PhD Dissertation, Université de la Méditerranée, France.

Ledoux J, Garrabou J, Bianchimani O et al. (2010a) Fine-scale genetic structure and inferences on population biology in the threatened Mediterranean red coral, Corallium rubrum. Molecular Ecology, 19, 4204-4216.

Ledoux J, Mokhtar-Jamaï K, Roby C et al. (2010b) Genetic survey of shallow populations of the Mediterranean red coral [Corallium rubrum (Linnaeus, 1758)]: new insights into evolutionary processes shaping nuclear diversity and implications for conservation. Molecular Ecology, 19, 675-690.

Lejeusne C, Chevaldonné P (2006) Brooding crustaceans in a highly fragmented habitat: the genetic structure of Mediterranean marine cave-dwelling mysid populations. Molecular Ecology, 15, 4123-4140.

Linares C, Doak D (2010) Forecasting the combined effects of disparate disturbances on the persistence of long-lived gorgonians: a case study of Paramuricea clavata. Marine Ecology Progress Series, 402, 59-68.

Linares C, Coma R, Diaz D et al. (2005) Immediate and delayed effects of a mass mortality event on gorgonian population dynamics and benthic community structure in the NW Mediterranean Sea. Marine Ecology Progress Series, 305, 127-137.

Linares C, Coma R, Garrabou J, Díaz D, Zabala M (2008a) Size distribution, density and disturbance in two Mediterranean gorgonians: Paramuricea clavata and Eunicella singularis. Journal of Applied Ecology, 45, 688-699.

Linares C, Coma R, Mariani S et al. (2008b) Early life history of the Mediterranean gorgonian Paramuricea clavata: implications for population dynamics. Invertebrate Biology, 127, 1-11.

Linares C, Coma R, Zabala M (2008c) Effects of a mass mortality event on gorgonian reproduction. Coral Reefs, 27, 27-34.

Linares C, Coma R, Zabala M (2008d) Restoration of threatened red gorgonian populations: an experimental and modelling approach. Biological Conservation, 141, 427-437.
Manel S, Schwartz MK, Luikart G, Taberlet P (2003) Landscape genetics: combining landscape ecology and population genetics. Trends in Ecology \& Evolution, 18, 189-197.

Manni F, Guerard E, Heyer E (2004) Geographic patterns of (genetic, morphologic, linguistic) variation: how barriers can be detected by using Monmonier's algorithm. Human Biology, 76, 173-190.

Miller SA, Dykes DD, Polesky HF (1988) A simple salting out procedure for extracting DNA from human nucleated cells. Nucleic Acids Research, 16, 1215.

Millot C (1979) Wind induced upwellings in the Gulf of Lions. Oceanologica Acta, 2, 261-274.

Molecular Ecology Resources Primer Development Consortium, Aurelle D, Baker A et al. (2010) Permanent genetic resources added to the molecular ecology resources database 1 February 2010-31 March 2010. Molecular Ecology Resources, 10, 751-754. http:/ / tomato.bio.trinity.edu/manuscripts/10-4/mer-10-0076.pdf

Monmonier M (1973) Maximum-difference barriers: an alternative numerical regionalization method. Geographical analysis, 5, 245-261.

Monserrat S, López-Jurado J, Marcos M (2008) A mesoscale index to describe the regional circulation around the Balearic Islands. Journal of Marine Systems, 71, 413-420.

Moran PAP (1948) The interpretation of statistical maps. Journal of the Royal Statistical Society. Series B (Methodological), 10, 243-251.

Nei M (1973) Analysis of gene diversity in subdivided populations. Proceedings of the National Academy of Sciences of the United States of America, 70, 3321-3323.

Öztürk B, Aktan Y, Topaloglu B et al. (2004) Marine life of Turkey in the Aegean \& Mediterranean Seas. Turkish Marine Research Foundation (TÜDAV) Publications. Marine Education Series. Number 10. Istanbul, Turkey, 200 p.

Paetkau D, Slade R, Burden M, Estoup A (2004) Genetic assignment methods for the direct, real-time estimation of migration rate: a simulation-based exploration of accuracy and power. Molecular Ecology, 13, 55-65.

Palumbi SR (1992) Marine speciation on a small planet. Trends in Ecology \& Evolution, 7, 114-118.

Palumbi SR (1994) Genetic divergence, reproductive isolation, and marine speciation. Annual Review of Ecology and Systematics, 25, 547-572.

Palumbi SR (2004) Marine reserves and ocean neighborhoods: the spatial scale of marine populations and their management. Annual Review of Environment and Resources, 29, 31-68.

Patarnello T, Volckaert FAMJ, Castilho R (2007) Pillars of Hercules: is the Atlantic-Mediterranean transition a phylogeographical break? Molecular Ecology, 16, 4426-4444.

Pérez-Portela R, Turon X (2008) Cryptic divergence and strong population structure in the colonial invertebrate Pycnoclavella communis (Ascidiacea) inferred from molecular data. Zoology, 111, 163-178.

Pinardi N, Masetti E (2000) Variability of the large scale general circulation of the Mediterranean Sea from observations and modelling: a review. Palaeogeography, Palaeoclimatology, Palaeoecology, 158, 153-173.

Piry S, Alapetite A, Cornuet J et al. (2004) GENECLASS2: a software for genetic assignment and first-generation migrant detection. Journal of Heredity, 95, 536-539.

Polato NR, Concepcion GT, Toonen RJ, Baums IB (2010) Isolation by distance across the Hawaiian Archipelago in the reefbuilding coral Porites lobata. Molecular Ecology, 19, 4661-4677. 
Pritchard JK, Stephens M, Donnelly P (2000) Inference of population structure using multilocus genotype data. Genetics, 155, 945-959.

Pritchard J, Wen X, Falush D (2007) Documentation for the STRUCTURE software, Version 2, Chicago. Available at http:/ / pritch.bds.uchicago.edu.

Rannala B, Mountain JL (1997) Detecting immigration by using multilocus genotypes. Proceedings of the National Academy of Sciences of the United States of America, 94, 9197-9201.

Ribes M, Coma R (2005) The role of engineer species in the benthic-pelagic coupling: the study case of a Mediterranean gorgonian. Limnology and Oceanography, Summer meeting, 128 (Abstract).

Rosenberg NA (2004) DISTRUCT: a program for the graphical display of population structure. Molecular Ecology Notes, 4, 137-138.

Rosenberg NA, Burke T, Elo K et al. (2001) Empirical evaluation of genetic clustering methods using multilocus genotypes from 20 chicken breeds. Genetics, 159, 699-713.

Rosenberg NA, Pritchard JK, Weber JL et al. (2002) Genetic structure of human populations. Science, 298, 2381-2385.

Rousset F (1997) Genetic differentiation and estimation of gene flow from F-statistics under isolation by distance. Genetics, 145, 1219-1228.

Rousset F (2008) GENEPOP'007: a complete re-implementation of the GENEPOP software for Windows and Linux. Molecular Ecology Resources, 8, 103-106.

Rozenfeld AF, Arnaud-Haond S, Hernández-García E et al. (2008) Network analysis identifies weak and strong links in a metapopulation system. Proceedings of the National Academy of Sciences, 105, 18824-18829.

Sala-Bozano M, Ketmaier V, Mariani S (2009) Contrasting signals from multiple markers illuminate population connectivity in a marine fish. Molecular Ecology, 18, 4811-4826.

Sanford E, Kelly MW (2011) Local adaptation in marine invertebrates. Annual Review of Marine Science, 3, 509-535.

Schwartz MK, Luikart G, Waples RS (2007) Genetic monitoring as a promising tool for conservation and management. Trends in Ecology \& Evolution, 22, 25-33.

Shanks AL, Grantham BA, Carr MH (2003) Propagule dispersal distance and the size and spacing of marine reserves. Ecological Applications, 13, 159-169.

Torrents O, Tambutté E, Caminiti N, Garrabou J (2008) Upper thermal thresholds of shallow vs. deep populations of the precious Mediterranean red coral Corallium rubrum (L.): Assessing the potential effects of warming in the NW Mediterranean. Journal of Experimental Marine Biology and Ecology, 357, 7-19.

True M (1970) Etude quantitative de quatre peuplements sciaphiles sur substrats rocheux dans la région marseillaise. Bulletin de l'Institut Océanographique de Monaco, 1410, 1-48.

Van Oosterhout CV, Hutchinson WF, Wills DPM, Shipley P (2004) MICRO-CHECKER: software for identifying and correcting genotyping errors in microsatellite data. Molecular Ecology Notes, 4, 535-538.

Van Oppen MJHV, Gates RD (2006) Conservation genetics and the resilience of reef-building corals. Molecular Ecology, 15, 3863-3883.

Van Oppen MJH, Bongaerts P, Underwood JN, Peplow LM, Cooper TF (2011) The role of deep reefs in shallow reef recovery: an assessment of vertical connectivity in a brooding coral from west and east Australia. Molecular Ecology, 20, 1647-1660.

Wang S, Lewis CM, Jakobsson Met al. (2007) Genetic variation and population structure in native Americans. PLoS Genet, 3, e185.

Waples RS, Gaggiotti O (2006) What is a population? An empirical evaluation of some genetic methods for identifying the number of gene pools and their degree of connectivity. Molecular Ecology, 15, 1419-1439.

Weir BS, Cockerham CC (1984) Estimating F-statistics for the analysis of population structure. Evolution, 38, 1358-1370.

Williams SL (2001) Reduced genetic diversity in eelgrass transplantations affects both population growth and individual fitness. Ecological Applications, 11, 1472-1488.

This article is part of the PhD work of K.M.-J., which focuses on the application of genetic approaches to study the population structure, mating system and dispersal in Paramuricea clavata for conservation purposes. M.P. is an associate professor whose research focuses on molecular population studies of marine and model organisms. J.-B.L. is a post-doctoral researcher interested in the evolution and conservation of coastal marine invertebrates. R.C. is a researcher interested in understanding the structure and functioning of marine ecosystems. J.G. is a researcher involved in marine population and community studies focused on the conservation of long-lived invertebrates. J.-P.F. is a researcher interested in the ecology and evolution of marine biodiversity. D.A. is an associate professor interested in population genetics and adaptive processes.

\section{Data accessibility}

Microsatellite data set: DRYAD entry doi:10.5061/dryad.s01rg.

\section{Supporting information}

Additional supporting information may be found in the online version of this article.

Table S1 $\mathrm{f}$ estimator of $F_{\text {IS }}$ per sample and locus and null allele frequencies.

Table S2 Pairwise $F_{\mathrm{ST}}$ (upper right) and $D_{\mathrm{EST}}$ (lower left) values.

Table S3 Individuals assigned as first-generation migrants as estimated by GENECLASS2.

Fig. S1 Correlation between genetic distances computed as $F_{\mathrm{ST}} /\left(1-F_{\mathrm{ST}}\right)$ and the logarithm of geographical distances $(\mathrm{m})$ within the three regions: (a) Medes, (b) Marseille and (c) North Corsica.

Fig. S2 Plot of $\operatorname{LnP}(\mathrm{D})$ as a function of the number of clusters (K) across the 10 runs: (a) for the whole data set (first round) and (b) for each of the five clusters (second round).

Please note: Wiley-Blackwell are not responsible for the content or functionality of any supporting information supplied by the authors. Any queries (other than missing material) should be directed to the corresponding author for the article. 